\title{
NEW TRAJECTORIES OF POST-SOCIALIST RESIDENTIAL MOBILITY IN BUCHAREST
}

\author{
Bogdan Suditu ${ }^{\mathrm{a} *}$, Liliana Dumitrache ${ }^{\mathrm{a}}$, Daniel Vîrdol ${ }^{\mathrm{b}}$, Daniel-Gabriel Vâlceanu ${ }^{\mathrm{a}, \mathrm{c}}$ \\ ${ }^{a}$ Faculty of Geography, University of Bucharest, Romania \\ ${ }^{b}$ National Institute of Statistics, Bucharest, Romania \\ ${ }^{c}$ National Institute for Research and Development in Constructions,
}

Urbanism and Sustainable Spatial Development URBAN-INCERC, Bucharest, Romania

\begin{abstract}
Over the post-socialist period, residential mobility processes were very intense and took place on large areas. Flow intensity led to the emergence of new spatial and functional realities and created new relationships within the affected areas. During all this period, Bucharest's metropolitan area was shaped by the spatial mobility of the city dwellers, as well as by the change of their social and residential aspirations. The majority of those who were registered as movers in Bucharest were actually residents of Bucharest (they only changed their domicile) and the share of people coming to the city from elsewhere has increased constantly over the last decade. Except for the early 1990s, a period when residential legal status was pending clarification, migrations from peri-urban area, especially from Ilfov County, to Bucharest had a low intensity. Situation is quite different in terms of moving out of Bucharest, to the communes and towns of Ilfov County, located in close proximity, which have been continuously increasing values. The correlation between housing stock features (real estate supply) and the demand of new dwellings (emphasized by the residential trajectories) prove both that current mobility flows taking place at this time in Bucharest are segmented based on economic-spatial criteria and that Markov chains are functional.
\end{abstract}

Key words: Residential mobility, Housing stock, Post-socialist period, Bucharest.

Article Info: Manuscript Received: December 15, 2013; Revised: April 10, 2014; Accepted: May 10, 2014; Online: May 31, 2014.

\section{Introduction}

The change of the socialist political and economic system and its replacement with a form of liberalized capitalist economy, has led to new production techniques and distribution patterns of the dwellings, as well as to a radical transformation of social structures, urban residential areas and the social-residential meanings thereof. At the end of the socialist period, the laws and regulations that enforced an absolute control of the state in the field of property, residence and housing production were repealed, which explains the significant transformations that followed. Economic liberalization and the crisis generated by the subsequent decline of industry are the causes that stopped the housing production financed by public funds. At the same

\footnotetext{
* Corresponding author:

Address: University of Bucharest, Faculty of Geography,

1 Nicolae Bălcescu Avenue, 010041, Bucharest, Romania.

Telephone: +4 0213153074

Email: b_suditu@yahoo.fr
}

time, the flexible planning rules quickly led to a variety of private initiatives in the field of housing construction, to the conversion of residential areas and to the expansion of buildable urban space (Noica, 2003).

The geographical residential mobilities of Bucharest citizens, previously ordered, organized and controlled by the communist authorities, have become a spatialized form of expression of individual liberty and a personalized option of the residents in terms of housing and location.

The intensity recorded in the post-communist period by this socio-geographical process expresses, on the one hand, the need for certain housing quality standards, and on the other hand, the preference for a particular residential location. This latter aspect has strong social and behavioral connotations, highlighting hierarchies of individual preferences, but also hierarchies widely recognized of attractiveness or repulsion in the residential area of Bucharest, which currently extends beyond its administrative borders. 
Over the post-socialist period, residential mobility processes were very intense and took place on large areas. Flow intensity led to the emergence of new spatial and functional realities and created new relationships within the affected areas.

The removal of the legal restrictions and the liberal ideas manifested in the field of housing in the EasternEuropean countries were the main reasons for the appearance of new residential perimeters on the edge of the cities and for the alteration of the old residential functions of these areas. The new residential developments are functionally related to the big city and they mirror both the socio-professional transformations and the effect of incoherence or even the lack of public policies regarding urban housing.

During all this period, Bucharest's metropolitan area was shaped by the spatial mobility of the city dwellers, as well as by the change of their social and residential aspirations. Equally, these mobilities and the new housing patterns have led to urban sprawl and to a reconfiguration of the settlements affected by this phenomenon. In the context of the new urban-rural relationships, one can identify a number of elements that bring their contribution to laying the foundation principles of a new residential geography in the Bucharest's metropolitan area (Suditu, 2009).

\section{Definitions and methodology of spatial mobility}

Spatial mobility can be regarded as a mechanism of territorial adjustment of population distribution and, in its broadest sense, can be defined as ,all movements in the physical space of individuals or groups of individuals, irrespective of the duration and distance of movements" (Courgeau, 1988, p. 18). There are, however, differences in the definition and use of the forms of spatial mobility. The concept of migration frequently designates more or less explicitly international or interregional movements; geographical mobility concept generally includes these movements, and also movements within an agglomeration. But these two concepts do not account for swinging movements or "alternating migrations" or various other types of movements: business-related travel, recreation, trade or holidays. M.Bassand and M.-C.Brulhardt (1980) use the concept of spatial mobility, which they define as all movements of actors (individual or collective) in the physical (or geographical) space, whichever is the duration and distance, the means of transport used, the causes and the consequences.

In order to understand precisely the geographical mobility we must take into account two dimensions: space and duration. In demography, migration concept is defined as "a set of movements resulting in the transfer of residence from a particular place of origin or place of departure to a particular place of destination or place of arrival, the residence being the place where individuals use to live "(Henry, 1981, p.12). At the same time, because place identification depends on geographical location (neighborhood, sector, agglomeration etc.), which varies according to country and statistical sources, the residence is commonly used as reference point (Cadwallader, 1992; Courgeau, 2000).

Therefore a change of residence within a certain period allows the recording of residential mobility.

Depending on the spatial landmarks that define the living space and the administrative boundaries of the areas in which statistical recordings are made, mobilities may be seen as residential mobilities or migrations (Dumitrache, Suditu, 200o). In Romania, statistical tools do not record the residential mobilities taking place within the same administrative unit. Thus, any population mobility experienced by a small- or medium-size city within its boundaries is not statistically highlighted, because statistically speaking the city represents a single administrative unit and people changing residence are not considered to cross an administrative border. As far as Bucharest is concerned, which is a major city, the same deficiency of statistical records prevents us of having a clear image of the mobilities taking place within the six administrative sectors (each of them having more than 250,000 inhabitants). These specific features of the statistical system allow us to analyze only the information regarding the mobility of the people who have crossed the sector borders (intersectoral movements) or the administrative boundaries of the city.

\section{Paradigm shift regarding the social structures and spatial mobilities of the post-socialist period}

In post-socialist Bucharest, the neighbourhoods built previously are still part of the new residential geography of the city, but they have lost their socio-spatial significance. The "homogenized" social structures of the past suffer significant changes, professional groups being the most affected by the new economic reform (Gavriș, 2011). Urban proletariat gradually loses its advantages, the one that will be the most severely affected by the restructuring of large industrial plants.

Many workers who lost their jobs in the 1990 os were not able to adapt to the new labor market and the new economic and urban rules, being forced or proffering to leave Bucharest and go to their place of origin.. The liberalization of real estate market implies a free competition in house purchasing. Since 1990, the state has encouraged the tenants to buy the houses they lived in and, consequently, most of the apartments passed into private ownership, becoming subsequently the subject of numerous real estate transactions. 
Thus, the city begins to change its appearance, with different rhytms and directions. The houses and residential areas are capitalized in various ways on the real estate market. New residential hierarchies will segment the residential housing stock, depending on the housing type, the services available to them and their location.

Besides, the urban residential competition will also encompass the new individual dwellings built at the beginning of the post-communist period either within the pre-existent residential areas or in the outer residential parks.

The diversification of housing stock is accompanied by the segmentation of the social structures, apparently homogenized during the previous period. The post-socialist residential Bucharest will gradually regain its social meanings, which will help to define new rules of intra-urban mobility.

The role of state in building houses gradually declines, but its concern for protecting the tenants living in the nationalized houses that have been not returned to their rightful owners is still high. State involvement in the post-socialist era in building houses for the disadvantaged categories of population is punctual and with no significant effects with regard to the housing stock or the socio-spatial architecture developed during this period. Urban competition and the emergence of new and powerful competitors in the field of urban housing have led to the functional fragmentation of the city, each area being governed by other rules and socio-residential meanings.

In Bucharest, the territorial development or the historical housing features allow us to distinguish a residential typology that encompasses perimeters in which the habitat is homogeneous, people have about the same age, and quality and comfort indicators are relatively similar. Radial development of the city, by building large residential complexes around the city center, thus covering the areas between the old center - which corresponds most to the interwar Bucharest and the villages-neighborhoods that became part of the city- has led to the differentiation of several types of residential areas, from the center outward (Nae, 2007; 2009).

More specifically, Bucharest residential space may be split into three major areas with relatively homogeneous features, each ot them comprising sub-areas of homogeneous habitat: the central area (the historical center, the area with traditional and spontaneous plotting, the civic center and the residential area with preestablished plotting); the intermediate area (the urban workers neighborhoods, the residential area with preestablished plotting); and the outer area (the large residential sites and the peripheral individual dwellings of rural origin) (Figure 1).

By its new services and implanted office buildings, the city becomes a space of economic "visibility", increasingly important, sought and appreciated. At the same time, as the importance of the relationships between the industrial sites and the large residential areas has decreased people orient themselves to the new service areas offering jobs, located in the center of the city or on the outskirts. The increasing importance of the center and its gentrification trend are marked by the gradual rehabilitation of the nationalized houses, which are traded on the real estate market.

Due to their attractiveness and accessible character, the intermediate areas with individual dwellings
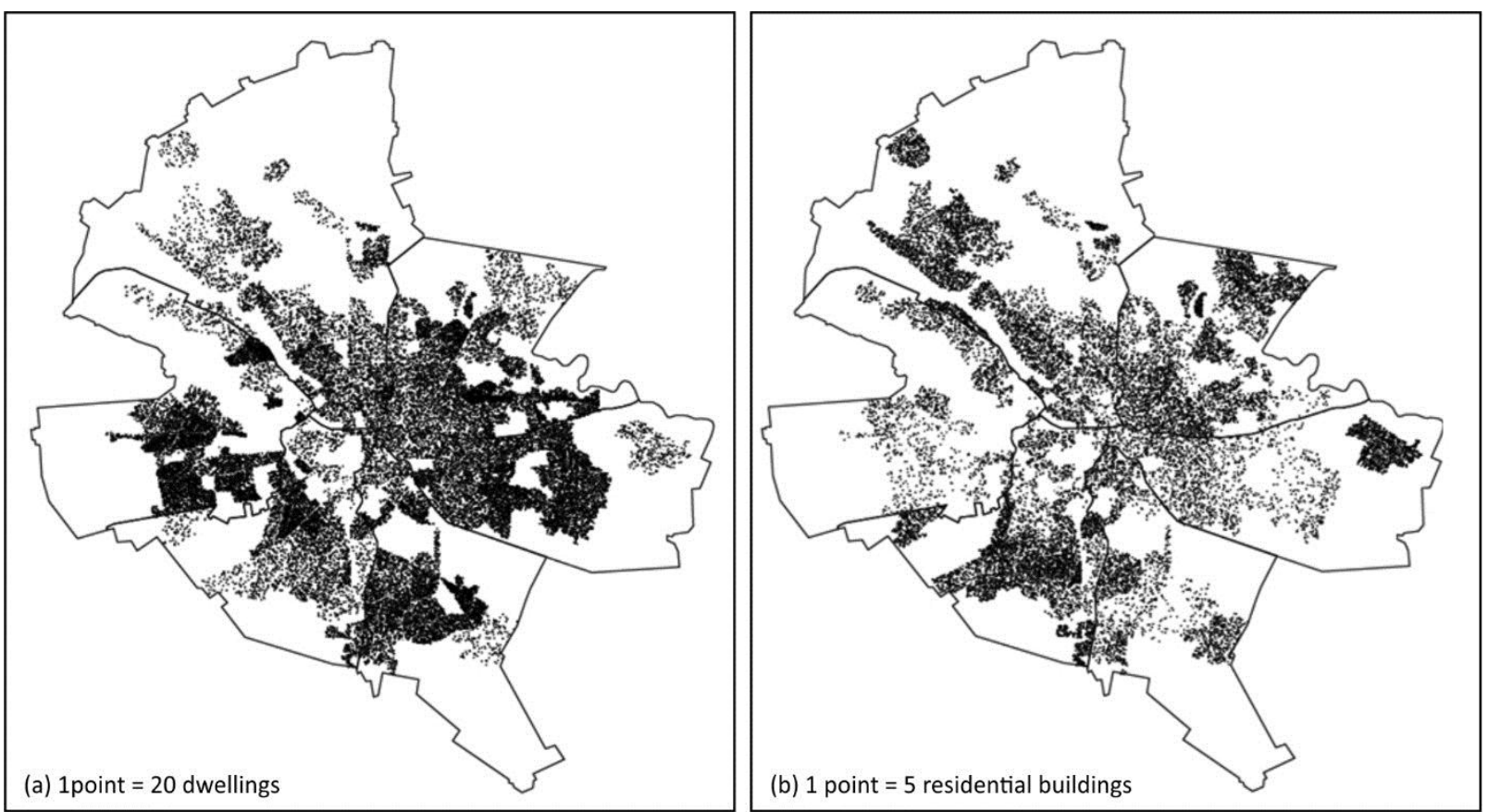

Figure 1. Distribution of dwellings and residential buildings in Bucharest (2002)

Source: Suditu, 2011 
were the first to be turned to account, the original houses being usually replaced by "villas" or small- or middle-size collective dwellings, which strongly changed the appearance of the entire area from the point of view of residential and social structure. For the inter-war villa parks located in the north, the transformations were not so drastic, because the restitution process and the reconstruction of ownership rights were delayed. Besides, building replacements have been punctual and irregular.

By size and variety, the large residential complexes remain the most fragmented and accessible urban space, being the area of ongoing residential itineraries of Bucharest inhabitants, almost regardless of age, socio-professional category or stage of their residential careers. The flats found in the collective dwellings often suffer modifications, re-arrangements or up-gradings. The recent public initiatives of building rehabilitation have changed the color of the edifices and their obsolete image, even though the technical solutions employed have sometimes blurred the particular architectural details (Nae, 2008). The outer areas with individual dwellings are the most dynamic in terms of building replacement and the improvement of housing conditions and urban services. Within these areas or on the free marginal spaces numerous pavilion housing estates have been built, which have become the residential target of the people with high revenues.

The post-socialist city organizes and develops itself according to ultra-liberal rules, while state intervention tools lose their force and meaning. The role of public authorities becomes secondary to the extensive planning process of residential space, to the housing policies or to the protection and support of the disadvantaged social groups. In this context, the residential mobility of Bucharest citizens, within or outside the city, is guided by the rules of market economy and is structured by the economic factors and the features of the housing stock.

\section{Trajectories of residential mobility: a diachronic and spatial perspective}

In the context of economic reorganization, marked by the loss of significance of industrial suburbs, the regaining of economic and commercial role of the city center, the removal of administrative barriers on the movement of persons and residence establishment, the emergence of new ways of living and of new economic stakeholders in the field of housing production and rehabilitation, post-socialist Bucharest has known a dramatic change. In this context, the characteristics of the housing stock as a whole, as well as those specific to each sector, influence and shape the direction and intensity of mobility flows.
The number of those who left Bucharest or move into the city during the post-socialist period rapidly grew in the early years (due to the great social shock determined by the numerous layoffs and factory closures) from 6,458 inhabitants in 1991 to 33,368 inhabitants in the following year (Figure 2). Subsequently, the number stabilized and kept around 35,00o people. Once the legal situation of the people who at the end of the previous period had not been able to establish legal residence in Bucharest was solved, the values recorded every year were stabilized or suffered minor deviations from the average.

The mobility in search of employment and change of population social status generate new residential trajectories within the city. Therefore, data referring to the changes of residence within Bucharest have recorded maximum values (Figure 3 ).

Many of those statistically recorded as moved-out, left a dwelling and moved to another one, also located in Bucharest, but in another sector. Thus, the mobility of Bucharest residents from sector to sector has significantly increased in terms of the share of people in the total mobilities of all kinds. The economic recovery and the increase of the number of newly built dwellings, as well as the mortgage system encouraging the access to property, have boosted the population mobility in all its components. The intensity of mobilities increased after 1999, reaching the highest values during the period 2002-2004, in a favorable economic context, and 2008-2010, thanks to the "Prima casa"(First house) Program, which facilitated access to housing to the young people who did not possess a dwelling. This has greatly boosted the real estate market and the dynamics of residential mobilities.

The values recorded at sector level highlight the differences between the number of outgoing people and the number of incoming ones in each of these administrative areas. The specific features of the habitat and of the old socio-demographic structures have led to a variation of the intensity of movers exchange, influencing the mobility balance. During the study period (2002-2012), the values of migration balance (including residential mobility) were negative for sectors 1 (with a minimum of $-4,388$ in 2011), 2 (-144 in 2011), 4 $(-191$ in 2012) and 6 (-86 in 2006).

By analyzing the number and share of moved-in or moved-out of Bucharest for each sector, one can ascertain that during the entire study interval many of the movers from sectors 1, 2, 4, 5 and 6 have left the city since 2009, while the percentages of the Bucharest residents who moved into these sectors in the total number of incoming people was rather stable over the period 2002-2008. The analysis of residence changes at sector level proves that after 2009 these phenomena were extremely dynamic, with a maximum recorded in 2010 for all the six sectors of the city $(15,007$ outgoing people from sector 1 in 2011 and 15,542 incoming people in sector 3) (Figure 4). 


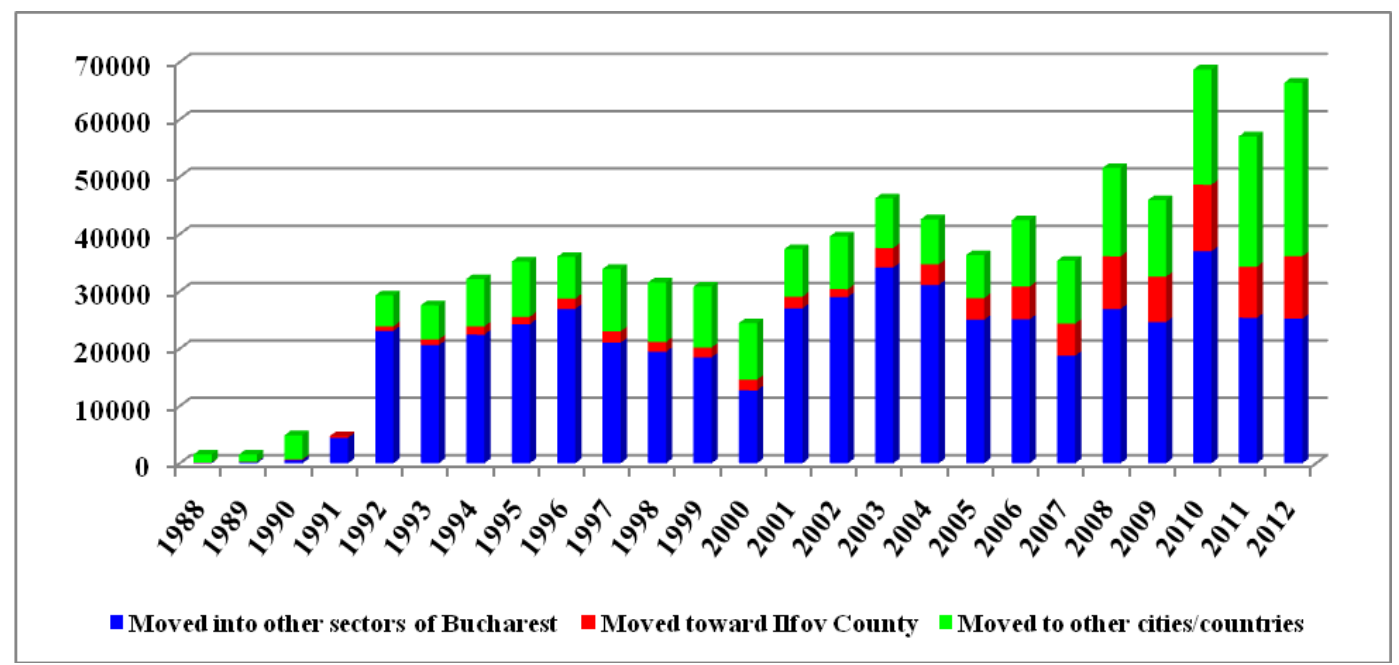

Figure 2. Dynamics of residential changes -residents moved into other sectors of Bucharest (by changing domicile ) in Ilfov county( peri-urban area) or in other counties or countries (1988-2012).

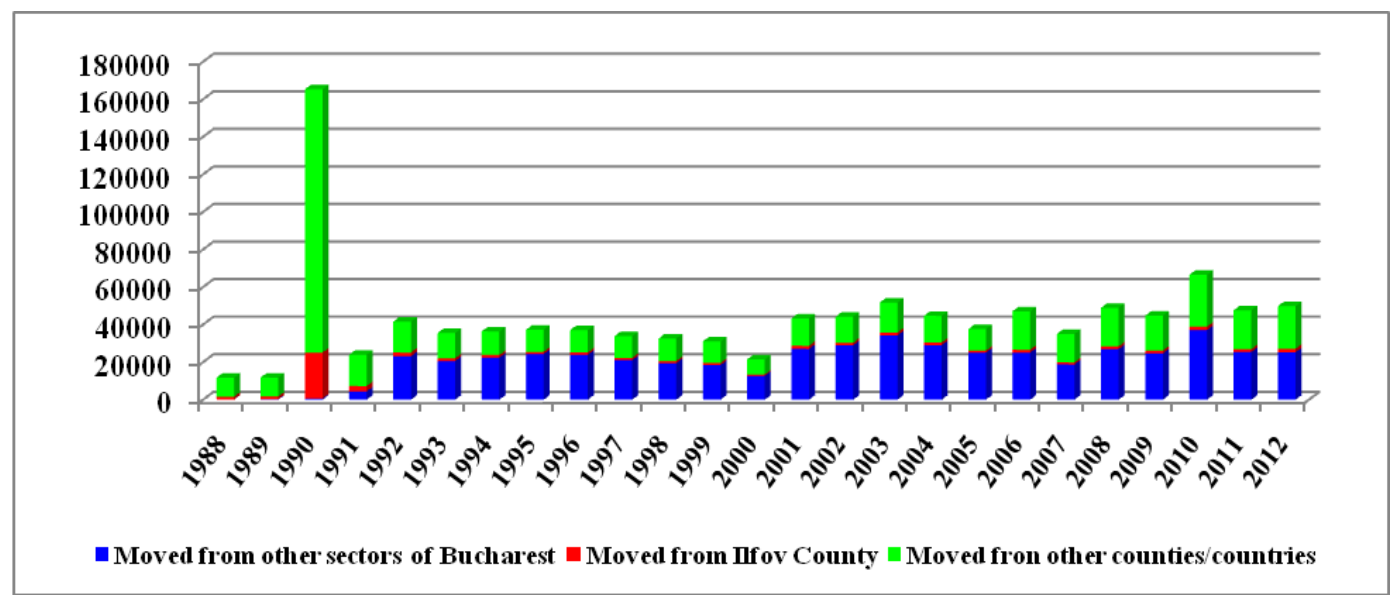

Figure 3. Dynamics of residential changes -residents moved from other sectors of Bucharest (by changing domicile ) from Ilfov county( peri-urban area) or from other counties or countries (1988-2012).

It can be noticed also that the majority of those who were registered as movers in Bucharest were actually residents of Bucharest (they only changed their domiciles) and the share of people coming to the city from elsewhere has increased constantly over the last decade.

Except for the early 1990s, a period when residential legal status was pending clarification, migrations from peri-urban area, especially from Ilfov County, to Bucharest had a low intensity. Situation is quite different in terms of moving out of Bucharest, towards the communes and towns of Ilfov County, located in close proximity, which have been continuously increasing values, especially after 2002.

The need for housing, usually an individual dwelling lying on the city's edge, providing a high level of comfort when compared with a collective dwelling, explains the mobility trend from the city center to the periphery.

\section{Dynamic and features of Bucharest' housing stock - source and framework for differentiated residential mobility}

The structures of Bucharest habitat and the old sociodemographic features have led to a change in the intensity of movers exchanges, with immediate effects emphasized by the mobility balance. In 2011, out of 844,587 dwellings recorded in Bucharest, only $12.73 \%$ were single-family homes, the rest of them being located in duplex housing or apartment buildings. At sector level, individual housing varied from more than $24 \%$ in sectors 1 and 5 , to $13.91 \%$ in sector $2,8.04 \%$ in sector 4 and $7.30 \%$ in sector 3 . In sector 6 , which is dominated by apartment buildings, the share of individual dwellings is only $5.06 \%$, despite the construction boom of the last decade. In the post-socialist period, the values of migratory balance (including residential mobility) have been constantly negative in sector 6 (with a minimum of $-1,785$ in 2000), sector 2 (1,176 in 1996) and sector $1(-1,709$ in 1999). 


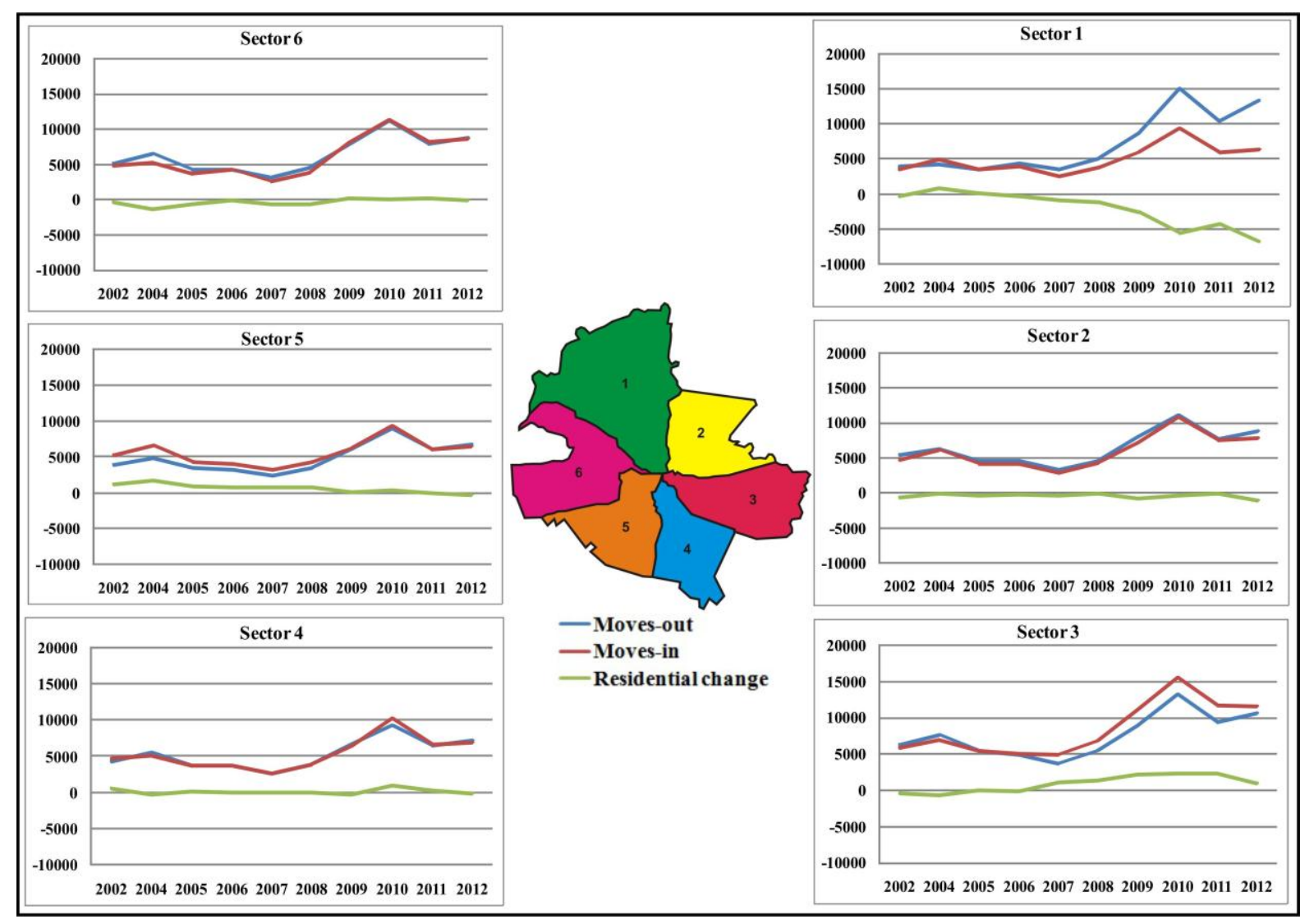

Figure 4. Dynamics of residential changes in Bucharest by sector (2002-2012)

Moreover, analyzing the number and the share of outgoing and incoming people for every sector, one can note that over the entire period many people from sectors 2, 3 and 6 left Bucharest, while the shares of incoming people have been about the same. The analysis of residence changes at sector level emphasizes the dynamics of these phenomena, but also the fact that most of them occur within the sectors.

The statistical characteristics of residential mobility values confirm the direct correlation among this element, the real estate dynamics, and the prevailing type of housing provided by every sector (Figure 5).

In sector 6, collective housing is predominant; here are located the large residential areas Drumul Taberei, Militari and Crângași - Giulești. In this area, residence changes have occurred within the existing housing stock, but to a less extent towards the newly built single-family homes, as it happened in other sectors. The same characteristics also apply to the housing stock of sectors 2, 3 and 4 . The qualitative difference of the habitat is quantitatively mirrored by the mean annual values of intra-urban mobility rates, which are higher or close to the average. In sectors 1 and 5, where the shares of individual dwellings are significant, the high rates of residence changes are proportional with the dynamics of housing stock. A lot of buildings have been erected in these two sectors, most of them individual dwellings, but also high-quality collective housing (in sector 1), which have replaced the demolished areas left derelict since the 1980 (the Uranus-Casa Poporului area in sector 5). The buildings have either been crammed on the already existing plots or have formed new residential areas (as is the case of Herăstrău - Pipera - Băneasa area in sector 1 or Prelungirea Ghencea in sector 5)

The recent dynamics of the housing stock suggests that every new built dwelling has a residential mobility. In fact, at this time, the real estate market and, implicitly, the residential mobility are highly segmented depending on the socio-economic specific features of the people involved. Individual housing requires high acquisition and modernization costs, thus being accessible only to a small number of people.

The apartments in the new collective housing are sought by mature or elder people with medium incomes, while those found in the old, inter-war blocks or in the communist edifices, being cheaper, are especially hunted by young people. The large number of investments made in the last decade in the field of housing construction, many of them for profiteering purpose, have led in the end to a balance between residential supply and demand. However, due to the high cost of credit and the limited results of the public policies and programs meant to ensure the competitivity of urban space, as well as accessible dwellings (privately owned or rented) for the people with low incomes, residential mobilities do not exceed the specified values. 

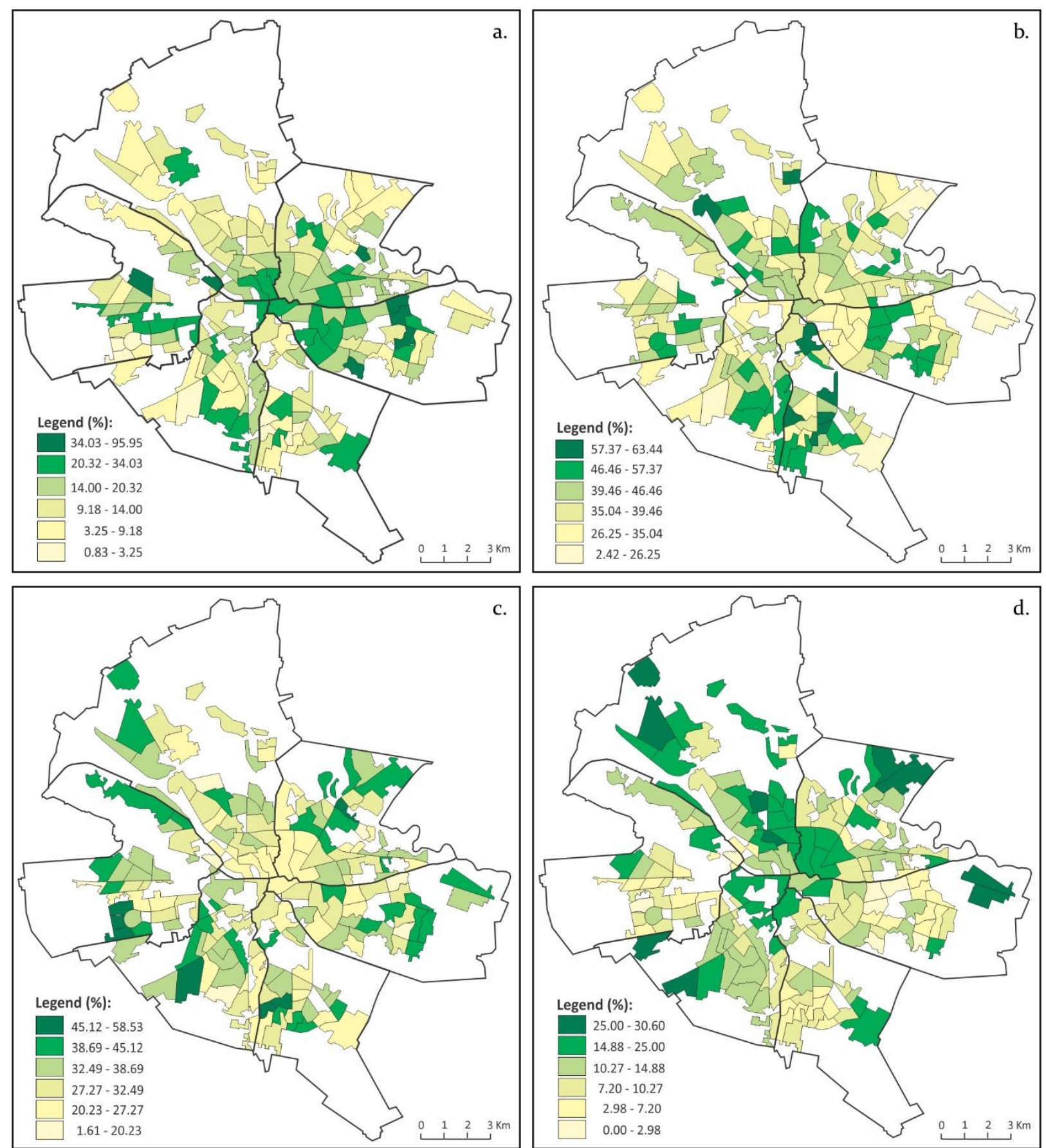

Figure 5. Share of dwellings with 1 room(a), 2 rooms(b), 3 rooms(c) 4 rooms and more (d) (2002) Source: Suditu, 2011

\section{Conclusions}

Spatial mobility can be regarded as a mechanism of territorial adjustment of population distribution. In post-socialist Bucharest, the neighborhoods built previously are still part of the new residential geography of the city, but they have lost their socio-spatial significance. The "homogenized" social structures of the past suffer significant changes, professional groups being the most affected by the new economic reform. Thus, the city begins to change its appearance, with different rhytms and directions.
The houses and residential areas are capitalized in various ways on the real estate market. New residential hierarchies will segment the residential housing stock, depending on the housing type, the services available to them and their location. The post-socialist residential Bucharest will gradually regain its social meanings, which will help to define new rules of intra-urban mobility. In this context, the characteristics of the housing stock as a whole, as well as those specific to each sector, influence and shape the direction and intensity of mobility flows. 
The number of those who left Bucharest or move into the city during the post-socialist period rapidly grew in the early years. Once the legal situation of the people who at the end of the previous period had not been able to establish legal residence in Bucharest was solved, the values recorded every year were stabilized or suffered minor deviations from the average.. Many of those statistically recorded as moved-out, left a dwelling and moved to another one, also located in Bucharest, but in another sector. Thus, the mobility of Bucharest residents from sector to sector has significantly increased in terms of the share of people in the total mobilities of all kinds. It can be noticed also that the majority of those who were registered as movers in Bucharest were actually residents of the city (they only changed their homes) and the share of people coming to the capital city from elsewhere has increased constantly over the last decade

The correlation between housing stock features (real estate supply) and the demand of new dwellings (emphasized by the residential trajectories) prove both that current mobility flows taking place at this time in Bucharest are segmented based on economicspatial criteria and that Markov chains are functional.

\section{References}

Abramo, P 1997, Marché et ordre urbain : du chaos à la théorie de la localisation résidentielle, L'Harmattan, Paris, 158p.

Bacaïni, B 200o,'Projet de mobilité et cadre de vie', Données Urbaines MF Mattei \& D Pumain (coord.), vol. 3, pp. 91-111. Bassand, M \& Brulhardt, MC 1980, Mobilité spatiale, Georgi, Saint-Saphorin.

Bonetti, M 1994, Habiter. Le bricolage imaginaire de l'espace, EPI, Paris.
Courgeau, D 1988, Méthodes de mesure de la mobilité spatiale : migrations internes, mobilité temporaire, navettes, INED, Paris.

Courgeau, D, Lelievre, E \& Wolber, O 1998,' Reconstruire des trajectoires de mobilité résidentielle', Economie \& Statistique, no. 316-317, pp. 163-173.

Dumitrache, L \& Suditu, B 200o,'Deplacements, mobilite residentielle, migrations - une approche theorique' in Regionalism and Integration-Culture,Space and Development, pp. 157-165, Editura Brumar, Timișoara.

Gavriș, A 2011, Mari habitate urbane din București - studiu de geografie urbană, Editura Universitară, București.

Knox, P \& Pinch, S 200o, Urban Social Geography. An Introduction (4th edition), Prentince Hall, Prenson.

Nae, M 2009, București - dezvoltare urbană şi calitatea vieții, Editura Universitară, București.

Nae, M 2008, Facteurs limitatifs de l'habitat urbain bucarestois lors de l'époque (post)transitionnelle à l'impact visible sur la qualité de vie', Analele Universității din București, Seria Geografie, an LV-2006, pp. 63-74.

Nae, M 2007, 'La taille des logements, densités élevées et attachement résidentiel - facteurs limitatifs de l'habitat urbain bucarestois', Human Geographies - Journal of Research in Human Geography, vol. 1, no. 1, pp. 114 -124

Noica, N 2003, Între istorie şi realitate. Politici de locuire în România, Editura Maşina de scris, Bucureşti.

Suditu, B 2009, 'Urban sprawl and residential mobilities in the Bucharest area - reconfiguration of a new residential geography', Human Geographies - Journal of Studies and Research in Human Geography, vol. 4, no.2, pp. 79-93.

Suditu, B 2011, Mobilități și strategii rezidențiale urbane și periurbane. Studiu de caz - București, Editura Universității din Bucuresti. 